\title{
Sodium Butyrate Attenuates Diarrhea in Weaned Piglets and Promotes Tight Junction Protein Expression in Colon in a GPR109A-Dependent Manner
}

\author{
Wenqian Feng ${ }^{a}$ Yancheng Wu ${ }^{a}$ Guangxin Chen ${ }^{a}$ Shoupeng Fu ${ }^{a} \quad$ Bai Lib \\ BingxuHuang ${ }^{a}$ Dali Wang ${ }^{a}$ Wei Wang $^{\mathrm{a}}$ Juxiong Liu ${ }^{\mathrm{a}}$

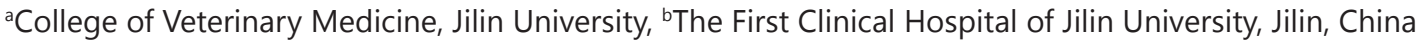

\author{
Key Words \\ Gpr109a $\cdot$ Akt $\cdot$ Caco-2 $\cdot$ Piglet $\cdot$ Tight junctions
}

\begin{abstract}
Background/Aims: Butyric acid plays an important role in maintaining intestinal health. Butyric acid has received special attention as a short-chain fatty acid, but its role in protecting the intestinal barrier is poorly characterized. Butyric acid not only provides energy for epithelial cells but also acts as a histone deacetylase inhibitor; it is also a natural ligand for $\mathrm{G}$ proteincoupled receptor 109A (GPR109A). A GPR109A analog was expressed in Sus scrofa and mediated the anti-inflammatory effects of beta-hydroxybutyric acid. This study investigated the effects of butyrate on growth performance, diarrhea symptoms, and tight junction protein levels in 21-day-old weaned piglets. We also studied the mechanism by which butyric acid regulates intestinal permeability. Methods: Twenty-four piglets that had been weaned at an age of 21 days were divided randomly into 2 equal groups: basal diet group and sodium butyrate + basal diet group. Diarrhea rate, growth performance during 3 weeks of feeding on these diets were observed, the lactulose-mannitol ratio in urine were detected by High Performance Liquid Chromatography, the expression levels of tight junction proteins in the intestinal tract and related signaling molecules, such as GPR109A and Akt, in the colon were examined by quantitative real-time PCR or western blot analyses on day 21 . Caco-2 cells were used as a colon cell model and cultured with or without sodium butyrate to assess the expression of tight junction proteins and the activation of related signaling molecules. GPR109A-short hairpin RNA (shRNA) and specific antagonists of Akt and ERK1/2 were used as signaling pathway inhibitors to elucidate the mechanism by which butyric acid regulates the expression of tight junction proteins and the colonic epithelial barrier. Results: The sodium butyrate diet alleviated diarrhea symptoms and decreased intestinal permeability without affecting the growth of early weaned piglets. The expression levels of the tight junction proteins Claudin-3, Occludin, and zonula occludens 1 were up-regulated by sodium butyrate




\section{Cellular Physiology Cell Physiol Biochem 2018;47:1617-1629 \begin{tabular}{l|l} 
DOI: 10.1159/000490981 & O 2018 The Author(s). Published by S. Karger AG, Basel \\
www.karger.com/cpb
\end{tabular} \\ Feng et al.: Sodium Butyrate Promotes Claudin-3 Expression in Colon via GPR109A}

in the colon and Caco-2 cells. GPR109A knockdown using shRNA or blockade of the Akt signaling pathway in Caco-2 cells suppressed sodium butyrate-induced Claudin-3 expression. Conclusions: Sodium butyrate acts on the Akt signaling pathway to facilitate Claudin-3 expression in the colon in a GPR109A-dependent manner.

\section{Introduction}

(C) 2018 The Author(s)

Published by S. Karger AG, Basel

With the intensive and large-scale development of the pig industry, the early weaning of piglets has become a universal goal in pig production. However, early weaning causes a series of adverse effects on the growth and development of piglets due to nutritional, immunological, psychological, and environmental stress. The main symptoms are diarrhea, stunted growth, and high mortality. Diarrhea is a major challenge for neonatal and postweaning piglets, and results in a reduced growth rate, increased morbidity and mortality, and large economic losses in the global swine industry [1]. Nutritionists have devised a series of solutions such as adding antibiotics, probiotics, enzymes, and oligosaccharides to feed. However, the use of antibiotics can increase the antibiotic resistance of pathogens and endanger human health $[2,3]$. Similar to antibiotics, the addition of organic acids or their salts to the diet has been shown to relieve diarrhea in weaned piglets [4]. As a physiological small-molecule derived from the microbial fermentation of dietary fibers, butyric acid has received special attention among short-chain fatty acids. Butyrate is naturally present in the gut, milk, sweat, and feces of most mammals. Butyric acid provides energy for intestinal epithelial cells and exerts immunomodulatory and anti-inflammatory effects on intestinal inflammation [5]. Butyrate or sodium butyrate has been reported to decrease intestinal permeability and enhance the intestinal barrier [6-8]. Intestinal permeability is related to diarrhea; thus, sodium butyrate decreases the incidence of diarrhea in weaned piglets. However, the mechanisms remain unclear $[4,9]$.

G protein-coupled receptor 109A (GPR109A; HM74A or HCA2 in humans) belongs to the niacin receptor family [10-12]. Sodium butyrate and $\beta$-hydroxybutyric acid are endogenous GPR109A ligands that activate the GPR109A receptor and inhibit inflammation and carcinogenesis [13, 14]. GPR109A is the major receptor for butyric acid in colonic epithelial cells and protects against colitis [15]. As shown in our previous studies, the AMP010014A09 gene in Sus scrofa encodes an analog of GPR109A that exhibits high nucleotide homology and amino acid identity and similarity to HM74A [16]. We hypothesized that sodium butyrate activates the GPR109A analog in piglets and causes a series of biochemical reactions to protect against diarrhea after weaning. The aim of this study was to determine whether the activation of GPR109A by sodium butyrate triggers the activation of a series of signaling pathways that alter the expression of tight junction proteins and decrease the permeability of the colon.

\section{Materials and Methods}

\section{Materials}

Sodium butyrate was purchased from Aladdin (Shanghai, China). Antibodies againstp-ERK1/2 (Thr202/ Tyr204), ERK1/2 (Thr202/Tyr204), Akt (Ser473), p-Akt (Ser473), p-P38 (Thr180/Tyr182), and P38 (Thr180/Tyr182) were purchased from Cell Signaling Technology (Danvers, MA, USA). Antibodies against zonula occludens 1 (ZO-1; ab59720), Occludin (ab31721), and Claudin-3 (ab15102) were purchased from Abcam (Cambridge, UK). Dulbecco's Modified Eagle's Medium Nutrient Mixture was obtained from Gibco Life Technologies, Inc. (Grand Island, NY, USA). Fetal bovine serum was purchased from Clark (Australia). TRIzol was obtained from Invitrogen (Carlsbad, CA, USA). 2× Taq Master Mix was purchased from Vazyme (Nanjing, China). A SYBR Green QuantiTect RT-PCR Kit and X-treme GENE HP DNA transfection reagent were obtained from Roche (South San Francisco, CA, USA). Polybrene was obtained from Sangon Biotech Co., Ltd. (Shanghai, China). The pGPU6-GFP-Neo-AMP+-sus-392 plasmid was used to decrease GPR109A 


\section{Cellular Physiology Cell Physiol Biochem 2018;47:1617-1629 \begin{tabular}{l|l} 
and Biochemistry Published 10.1159/000490981 & $\begin{array}{l}\text { (c) } 2018 \text { The Author(s). Published by S. Karger AG, Basel } \\
\text { www.karger.com/cpb }\end{array}$ \\
\hline
\end{tabular} \\ Feng et al.: Sodium Butyrate Promotes Claudin-3 Expression in Colon via GPR109A}

expression in Caco-2 cells. The selective inhibitors U0126 (ERK1/2), MK2206 (Akt), and SB203580 (P38) were purchased from Selleckchem (Houston, DE, USA).

\section{Animals and treatment}

The animals used for the experiments were provided by the breeding pig farm at Jilin University. All procedures performed on experimental animals were approved by the Jilin University Institutional Animal Care and Use Committee, according to the Guidelines for the Care and Use of Laboratory Animals in China. All pigs were provided with food and water ad libitum. Twenty-four Landrace weaned piglets were used in the experiments. The normal control group $(\mathrm{n}=12)$ was fed the basal diet consisting of a typical commercial post-weaning diet [17], and the sodium butyrate treatment group $(\mathrm{n}=12)$ was fed the basal diet supplemented with $2000 \mathrm{mg} / \mathrm{kg}$ sodium butyrate. The experiment lasted for 21 days.

A human colonic epithelial cell line (Caco-2) was purchased from the Cell Bank of Shanghai, Institute of Cell Biology, Chinese Academy of Sciences (Shanghai, China), and was maintained in a standard culture medium consisting of Dulbecco's Modified Eagle's Medium supplemented with 10\% fetal bovine serum, 50 $\mathrm{U} / \mathrm{mL}$ penicillin, and $50 \mu \mathrm{g} / \mathrm{mL}$ streptomycin (Gibco Life Technologies, Inc.). The cells were collected every 2 or 3 days until they reached $80-90 \%$ confluence.

\section{Data collection}

During the 21-day experiment, weaned piglets were weighed every 7 days, and the diet used for the experiment was recorded weekly. Diarrhea was observed at 09:00 and 16:00 daily. The standard grade of diarrhea was scored as follows: liquid $=3$, semiliquid $=2$, semisolid $=1$, and solid $=0$ [4].

\section{Intestinal permeability}

Weaned piglets were starved for $6 \mathrm{~h}$ to determine baseline urine sugar levels. Then, $500 \mathrm{mg} / \mathrm{kg}$ lactulose ( $3 \mathrm{~g} / 10 \mathrm{~mL}$; Shanghai Yuanye Bio-Technology Co., Ltd., Shanghai, China) and $50 \mathrm{mg} / \mathrm{kg}$ mannitol (0.3 g/10 $\mathrm{mL}$; Shanghai Yuanye Bio-Technology Co., Ltd.) were administered intragastrically to weaned piglets on days 7,14 , and 21 . The piglets were feed-deprived for the 6-h study period, but were allowed to drink water after $30 \mathrm{~min}$. The lactulose-mannitol ratio in urine was detected using high-performance liquid chromatography to reflect intestinal permeability accurately.

\section{Sample collection}

After 21 days, portions of the duodenum, jejunum, ileum, and colon were collected, washed with cold phosphate-buffered saline (PBS), and stored at $-80^{\circ} \mathrm{C}$ until protein or mRNA extraction. Then, 1 -cm portions of the duodenum, jejunum, ileum, and colon were fixed with $4 \%$ formaldehyde for $12 \mathrm{~h}$, embedded in paraffin, and sectioned.

\section{Treatment of Caco-2 cells}

Recombinant human tumor necrosis factor (TNF)- $\alpha$ (R\&D Systems, Minneapolis, MN, USA) was dissolved in sterile PBS to a concentration of $100 \mu \mathrm{g} / \mathrm{mL}$ along with $0.1 \%$ human or bovine serum albumin (BSA). This solution was used to destroy cell permeability. Caco- 2 cells were divided into 3 groups: control group, TNF- $\alpha(150 \mathrm{ng} / \mathrm{mL})$ treatment group, and TNF- $\alpha(150 \mathrm{ng} / \mathrm{mL})$ and sodium butyrate $(1.5 \mathrm{mM})$ treatment group. The cells were starved for $4 \mathrm{~h}$ and then pre-treated with sodium butyrate for $1 \mathrm{~h}$ before TNF- $\alpha$ was added. Caco- 2 cells were collected after $48 \mathrm{~h}$ to detect the expression of the intracellular tight junction protein Claudin-3. Each experiment was repeated 3 times.

\section{Electrical resistance measurements}

Permeability experiments were performed on Caco-2 cell monolayers grown in culture inserts comprising a microporous transparent bioporous membrane (Millicell CM; Millipore, Bedford, MA, USA). The cells were seeded into culture inserts at a density of $1.0 \times 10^{6}$ cells per insert. The medium $(200 \mu \mathrm{L}$ in the insert and $800 \mu \mathrm{L}$ in the well) was changed daily. Electrical resistance was measured using the MillicellElectrical Resistance System (Millipore). Once the trans-epithelial resistance (TEER) values had stabilized at $313 \pm 21 \Omega$, the cells in the inserts were ready for experimentation. The TEER values of the Caco- 2 cell monolayers were measured at $24 \mathrm{~h}$ after the addition of $1.5 \mathrm{mM}$ sodium butyrate, and TEER was calculated in ohms using the formula $\left(\mathrm{R}_{\text {sample }}-\mathrm{R}_{\text {blank }}\right) \times$ membrane area $\left(\mathrm{cm}^{2}\right)$. 


\section{Cellular Physiology Cell Physiol Biochem 2018;47:1617-1629 and Biochemistry Published online: June 27, $2018 \quad$\begin{tabular}{l|l} 
DOI: 10.1159/000490981 2018 The Author(s). Published by S. Karger AG, Basel \\
www.karger.com/cpb
\end{tabular} \\ Feng et al:: Sodium Butyrate Promotes Claudin-3 Expression in Colon via GPR109A}

RNA interference

GPR109A short hairpin

RNA (shRNA) was purchased from OLIGOBIO Biotechnology (Beijing, China) and mixed with X-treme GENE HP DNA transfection reagent (Roche) in 96-well plates, according to the manufacturer's instructions. The sequence of the recombinant plasmid was the same as the predicted sequence [16].

Quantitative real-time PCR

Total RNA was extracted from cells using TRIzol according to the supplier's protocol. RNA samples were extracted in sterile and RNase-free EP tubes during the extraction process, and cDNAs were synthesized using $2 \mu \mathrm{g}$ total RNA. Total RNA was treated with RNase-free DNase I and quantified by measuring the absorbance at 260 and $280 \mathrm{~nm}$. RNA was stored at $-80^{\circ} \mathrm{C}$ until analysis. The first reaction contained $2 \mu \mathrm{L}$ oligo(dT)18 primer, $1 \mu \mathrm{g}$ total RNA, $0.5 \mu \mathrm{L}$ recombinant RNase inhibitor, 4 $\mu \mathrm{L}$ of $5 \times$ Reverse Transcriptase M-MLV Buffer, $1 \mu \mathrm{L}$ dNTP mixture, and 0.5 $\mu \mathrm{L}$ Reverse Transcriptase M-MLV. The expression levels of TNF- $\alpha$, Claudin-3, Occludin, Z0-1, and GPR109A were calculated by comparing them with the levels of GAPDH (normalization control) using the comparative cycle threshold method. The primer sequences for the tested genes are shown in Table 1 (pig) and Table 2 (human).

\section{Western blot analysis}

The cells were collected in cold PBS and centrifuged at $3000 \times g$ for $10 \mathrm{~min}$ at $4^{\circ} \mathrm{C}$. The cells were lysed in P0013B containing phosphatase inhibitors and PMSF. Then, $50 \mu$ g extracted protein was separated by $12 \%$ sodium dodecyl sulfate-polyacrylamide gel electrophoresis and transferred to a polyvinylidene fluoride membrane (Chemicon International, Millipore). The membrane was blocked with $5 \%$ milk for $2 \mathrm{~h}$. The target bands were excised and incubated with the following specific antibodies overnight at $4{ }^{\circ} \mathrm{C}$ : $\beta$-tubulin $(1: 40$, 000), p-P38 (1:2000), P38 (1:1000), p-ERK1/2 (1:2000), ERK1/2 (1:2000), Akt (1:1000), p-Akt (1:1000), Claudin-3 (1:1000), Occludin (1:1000), and GPR109A (1:100). The blots were washed 4 times with TBST for 15 min each and incubated with a goat anti-rabbit IgG-HRP (1:2000; Santa Cruz Biotechnology, Dallas, TX, USA) or goat anti-mouse IgG-HRP antibody (1:2000; Santa Cruz Biotechnology) for $1 \mathrm{~h}$ at room temperature. The blots were again washed 4 times with TBST for $15 \mathrm{~min}$ each. The immunoreactive proteins were developed with an ECL detection system (Millipore). All results were normalized to $\beta$-tubulin and are expressed as relative values compared with those of the control group. Each experiment was repeated 3 times.

\section{Immunofluorescence staining}

Paraffin sections were deparaffinized and rehydrated using successive soakings in xylene and alcohol. The paraffin sections were incubated with $0.5 \%$ Triton X-100 for $1 \mathrm{~h}$ at room temperature and then washed them 3 times with PBS for 3 min each. The sections were blocked with $100 \mu \mathrm{L}$ of $5 \%$ BSA for $30 \mathrm{~min}$. The sections were incubated with $100 \mu \mathrm{L}$ of solutions containing an antibody against Claudin-3 (1:50) in 5\% BSA overnight at $4^{\circ} \mathrm{C}$. Next, the sections were washed 4 times with PBST for 5 min each prior to incubation with goat anti-rabbit IgG (green) in 5\% BSA for $60 \mathrm{~min}$ in the dark. The sections were mounted with DAPI for $10 \mathrm{~min}$, and fluorescence was detected using a confocal microscope. 


\section{Cellular Physiology Cell Physiol Biochem 2018;47:1617-1629 \begin{tabular}{l|l} 
and Biochemistry & DOI: 10.1159/000490981 \\
Published 2018 The Author(s). Published by S. Karger AG, Basel \\
www.karger.com/cpb
\end{tabular}

\section{Statistical analysis}

The results are expressed as the mean \pm standard deviation. The data were analyzed using the statistical software package SPSS 12.0 (SPSS, Inc., Chicago, IL, USA). Differences between the groups were compared using one-way analysis of variance followed by the least significant difference test. P-values less than 0.05 were considered statistically significant, and values less than 0.01 were considered markedly significant.

\section{Results}

Sodium butyrate diet alleviates diarrhea symptoms without affecting the growth performance of early weaned piglets

We first evaluated diarrhea in early weaned piglets after 21 days of feeding on a standard diet containing or lacking sodium butyrate. The diarrhea rate, frequency, and index were significantly decreased $(\mathrm{P}<0.05)$ in piglets fed the diet supplemented with $2000 \mathrm{mg} /$ $\mathrm{kg}$ sodium butyrate (Table 3 ) compared with the piglets in the control group. The sodium butyrate group showed a higher average daily gain $(0.02 \pm 0.00)$ and lower feed gain ratio $(8.52 \pm 0.15)$ than the control group $(0.01 \pm 0.00, \mathrm{P}=0.0349$ and $25.82 \pm 0.30, \mathrm{P}=0.0259$, respectively) after the first week. However, significant differences in the average daily gain, average daily feed intake, and feed gain ratio were not observed between the control and sodium butyrate groups at other phases over the next 3 weeks and throughout the time course of this study (Table 4). Sodium butyrate effectively suppressed the expression of mRNA encoding the pro-inflammatory cytokine TNF- $\alpha$ in colon tissue (Fig. 1A)

\section{Sodium butyrate diet promotes intestinal barrier function and the expression of tight \\ junction proteins in colon tissue}

The lactulose-mannitol ratio in urine was determined on days 7,14, and 21 after weaning using high-performance liquid chromatography to assess intestinal permeability in piglets during the early weaning period. A low lactulose-mannitol ratios corresponds to reduced permeability, and greater permeability corresponds to more diarrhea. A significantly lower lactulose-mannitol ratio was detected in the urine of the sodium butyrate group $(\mathrm{P}<0.05)$ than in the control group at the time points tested here. This lower ratio represents the lower intestinal permeability and higher intestinal integrity of the sodium butyrate group (Fig. 1B). The expression of tightjunction proteins in the duodenum, ileum, jejunum, and colon was assessed using quantitative real-time PCR. Interestingly, significant changes in Claudin-3, Occludin, and ZO-1 expression were not observed in the duodenum or jejunum, regions that contribute to the enhancement of intestinal barrier function. Nevertheless, the sodium butyrate diet up-regulated Claudin-3 and Occludin expression in the ileum(Fig. 1C). Notably, higher expression levels of tight junction mRNAs encoding Claudin-3, Occludin, and ZO-1 were observed in the colon of the sodium butyrate group $(\mathrm{P}<$ 0.05 ) than in the control group (Fig. 1D), and the increased levels of Claudin-3 and Occludin proteins were confirmed by western blotting (Fig. 1E). Notably, the levels of Claudin-3 protein were increased in the colon of the sodium butyrate diet group, as determined by immunofluorescence staining (Fig. 1F).

Table 3. Diarrhea incidence in weaned piglets fed with or without adding $2000 \mathrm{mg} / \mathrm{kg}$ sodium butyrate in standard formula for 21 days $\left(\mathrm{n}=12,{ }^{*} \mathrm{P}<0.05\right.$, $\left.{ }^{* *} \mathrm{P}<0.01\right)$

\begin{tabular}{lccc}
\hline Items & control group & Sodium butyrate group & $\mathrm{p}$ Value \\
\hline Diarrhea incidence (\%) & $64.00 \pm 0.27$ & $9.10 \pm 0.10^{* *}$ & 0.0033 \\
Diarrhea frequency & $13.36 \pm 0.12$ & $1.91 \pm 0.05^{*}$ & 0.0132 \\
Diarrhea index & $1.820 \pm 0.11$ & $0.73 \pm 0.06^{*}$ & 0.0418 \\
\hline
\end{tabular}

Table 4. Performance in weaned piglets fed with or without adding $2000 \mathrm{mg} / \mathrm{kg}$ sodium butyrate in standard formula for 21 days $\left(\mathrm{n}=12,{ }^{*} \mathrm{P}<0.05,{ }^{* *} \mathrm{P}<0.01\right)$

\begin{tabular}{lccc}
\hline Items & control group & Sodium butyrate group & p Value \\
\hline Phase I (d 1to7) & & & \\
ADFI (kg) & $0.28 \pm 0.02$ & $0.18 \pm 0.01^{\mathrm{ns}}$ & 0.1508 \\
ADG (kg) & $0.01 \pm 0.00$ & $0.02 \pm 0.00^{*}$ & 0.0349 \\
F:G & $25.82 \pm 0.30$ & $8.52 \pm 0.15^{*}$ & 0.0259 \\
Phase II (d 8 to 14) & & & \\
ADFI (kg) & $0.34 \pm 0.30$ & $0.37 \pm 0.52^{\mathrm{ns}}$ & 0.0763 \\
ADG (kg) & $0.14 \pm 0.08$ & $0.19 \pm 0.23^{\mathrm{ns}}$ & 0.1893 \\
F:G & $2.39 \pm 0.88$ & $1.65 \pm 0.46^{\mathrm{ns}}$ & 0.4333 \\
Phase II (d 15 to 21) & & & \\
ADFI (kg) & $0.44 \pm 0.59$ & $0.39 \pm 0.46^{\mathrm{ns}}$ & 0.7576 \\
ADG (kg) & $0.31 \pm 0.47$ & $0.29 \pm 0.11^{\mathrm{ns}}$ & 0.1148 \\
F:G & $1.41 \pm 0.29$ & $1.17 \pm 0.34^{\mathrm{ns}}$ & 0.6136 \\
Overall (d 1 to 21) & & & \\
ADFI (kg) & $0.39 \pm 0.05$ & $0.36 \pm 0.03^{\mathrm{ns}}$ & 0.0941 \\
ADG (kg) & $0.16 \pm 0.03$ & $0.16 \pm 0.03^{\mathrm{ns}}$ & 0.6147 \\
F:G & $2.50 \pm 0.23$ & $2.20 \pm 0.29^{\mathrm{ns}}$ & 0.4336 \\
\hline
\end{tabular}




\section{Cellular Physiology \begin{tabular}{l|l} 
and Biochemistry Published online: June 27, 2018 & $\begin{array}{l}\text { C) } 2018 \text { The Author(s). Published by S. Karger AG, Basel } \\
\text { www.karger.com/cpb }\end{array}$ \\
\hline
\end{tabular}

Fig. 1. Effects of the sodium butyrate diet on intestinal permeability and the expression of TNF- $\alpha$, tight junction proteins in early weaned piglets. Piglets were fed a standard diet supplemented with or without $2000 \mathrm{mg} / \mathrm{kg}$ sodium butyrate for 21 days. (A) Effect of sodium butyrate on the expression of TNF- $\alpha$ mRNA in colon tissue $\left(n=3,{ }^{*} \mathrm{P}<0.05\right.$, ${ }^{* *} \mathrm{P}<0.01$ ). (B) The lactulose-mannitol ratio in urine was determined using high-performance liquid chromatography on days 7,14 , and 21 postweaning ( $\left.\mathrm{n}=6,{ }^{*} \mathrm{P}<0.05,{ }^{*} \mathrm{P}<0.01\right)$. (C) Effect of sodium butyrate on the expression of tight junction proteins in duodenum, ileum, and jejunum tissue from early weaned piglets $\left(\mathrm{n}=3,{ }^{*} \mathrm{P}<0.05\right.$, $\left.{ }^{* *} \mathrm{P}<0.01\right)$. (D) Expression of mRNAs encoding the tight junction proteins Claudin-3, Occludin and ZO-1 in the colon ( $\left.\mathrm{n}=3,{ }^{*} \mathrm{P}<0.05,{ }^{* *} \mathrm{P}<0.01\right)$. (E) Representative immunoblots and quantification of Claudin- 3 and Occludin expression $\left(\mathrm{n}=3,{ }^{*} \mathrm{P}<0.05\right.$, $* * \mathrm{P}<0.01)$. $(\mathrm{F})$ The expression of Claudin -3 protein in colon tissue was confirmed by immunofluorescence staining using an anti-Claudin-3 antibody (green) and DAPI (blue).

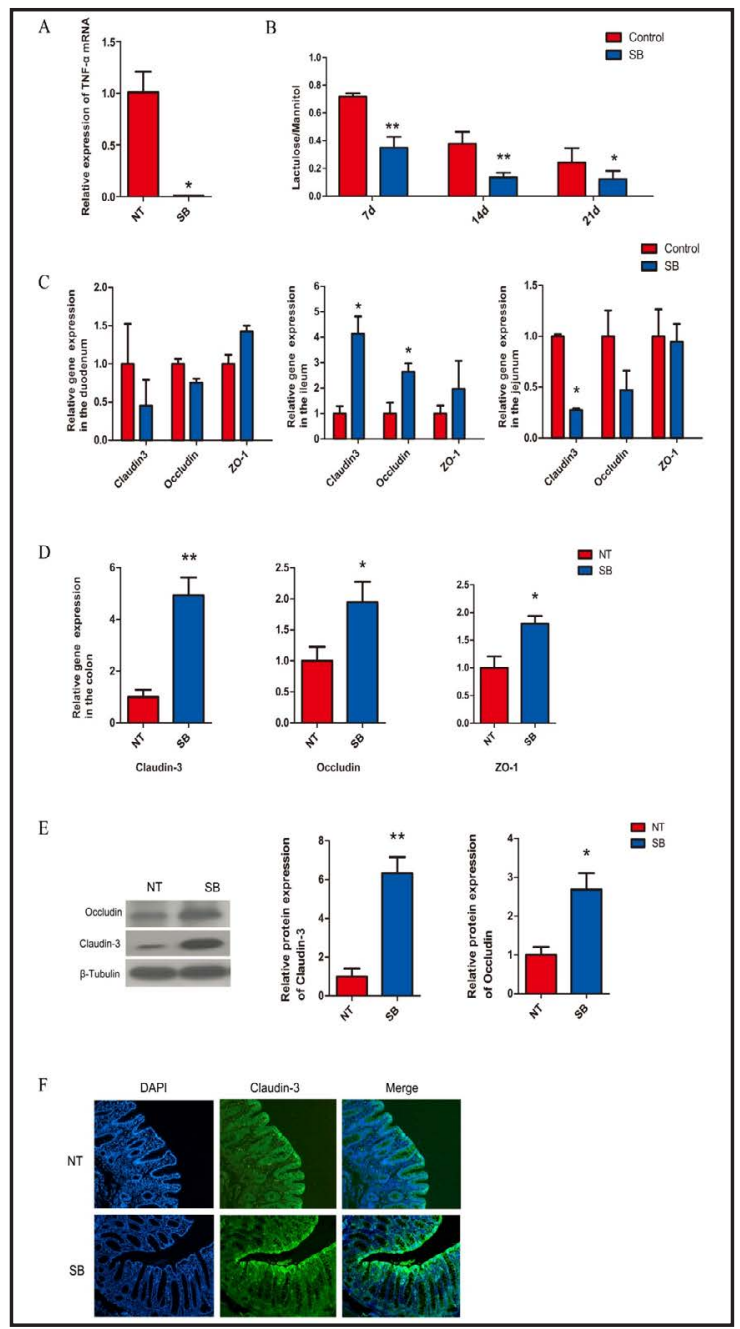

Sodium butyrate diet up-regulates GPR109A expression and promotes ERK1/2, P38, and Akt phosphorylation in the colon of piglets

The GPR109A receptor is activated by butyric acid, niacin, and $\beta$-hydroxybutyric acid, triggering the activation of a series of downstream signaling pathways. Western blot analysis was performed to detect the levels of phosphorylated transcription factors and protein kinases involved in intracellular signaling pathways in colon tissue to identify the signaling pathway that may mediate the effects of sodium butyrate. As shown in Fig. 2, the levels of phosphorylated ERK1/2, P38, and Akt were significantly increased in the colon of weaning piglets that were fed the basal diet supplemented with $2000 \mathrm{mg} / \mathrm{kg}$ sodium butyrate for 21 days. GPR109A receptor expression was also up-regulated by sodium butyrate in colon tissue. To identify further the effect of sodium butyrate on ERK1/2 and Akt activation in colonic epithelial cells, Caco- 2 cells were cultured in the presence of $1.5 \mathrm{mM}$ sodium butyrate for $5,15,30,60$, or 90 min to determine ERK1/2 and Akt phosphorylation. As shown in Fig. 3 , the levels of phosphorylated ERK1/2 and Akt were increased in Caco-2 cells after a 15-min treatment with sodium butyrate, which was consistent with the results for tissue obtained from the colon.

\section{Sodium butyrate promotes Claudin-3 expression in a colon epithelial cell line}

Caco-2 cells were used as a colon cell model to confirm the effects of sodium butyrate on Claudin-3 expression. As shown in Fig. 4A, treatment with 1, 1.5, or $2 \mathrm{mM}$ sodium butyrate for $48 \mathrm{~h}$ markedly increased the expression of Claudin-3 mRNA in Caco-2 cells. The incubation 


\section{Cellular Physiology Cell Physiol Biochem 2018:47:1617-1629 and Biochemistry \begin{tabular}{c|c} 
DOI: 10.1159/000490981 \\
Published online:June 27, 2018 & $\begin{array}{l}\text { O 2018 The Author(s). Published by S. Karger AG, Basel } \\
\text { www.karger.com/cpb }\end{array}$
\end{tabular} \\ Feng et al.: Sodium Butyrate Promotes Claudin-3 Expression in Colon via GPR109A}

Fig. 2. Effect of the sodium butyrate diet on GPR109A expression and ERK1/2, P38, and Akt phosphorylation in the colon of piglets fed a basal diet supplemented with $2000 \mathrm{mg} / \mathrm{kg}$ sodium butyrate for 21 days $\left(\mathrm{n}=3,{ }^{*} \mathrm{P}<0.05,{ }^{*} \mathrm{P}<0.01\right)$. (A) Representative immunoblots of ERK1/2, P38, Akt, GPR109A, and $\beta$-tubulin. (B-D) Quantification of the relative levels of phosphorylated ERK1/2, P38, and Akt in the colon of weaning piglets. (E) Quantification of the relative levels of the GPR109A receptor.
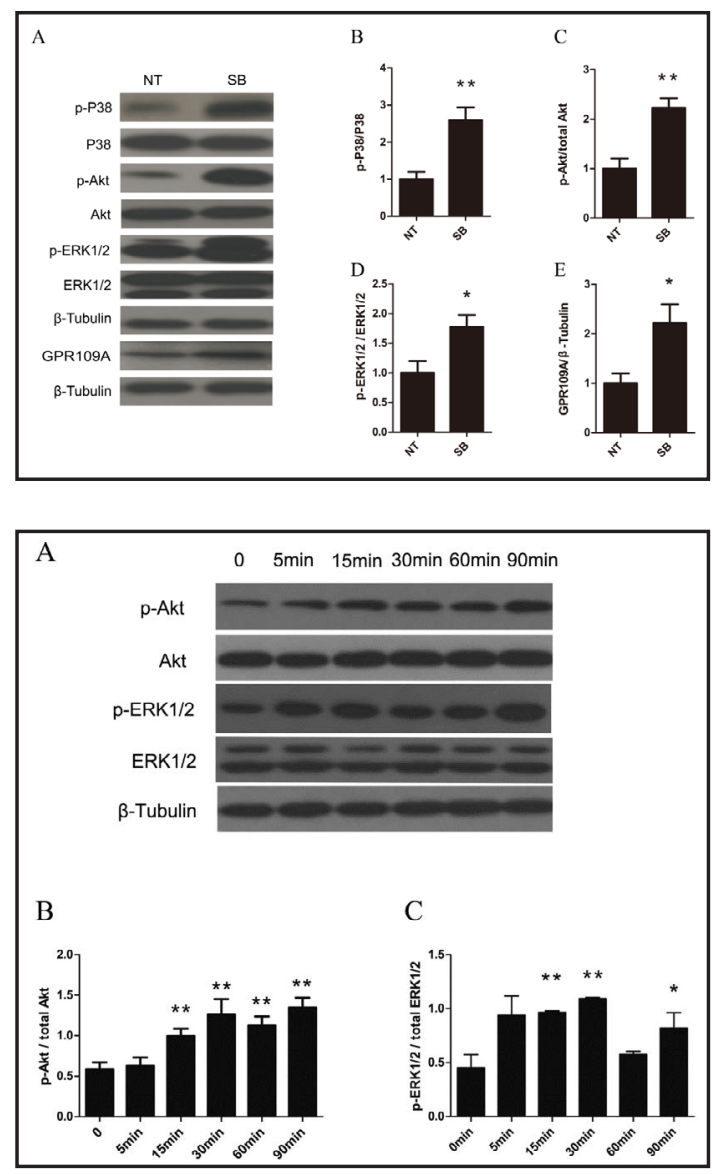

Fig. 4. Effects of sodium butyrate on Claudin-3 expression in a colon epithelial cell line. (A) Expression of Claudin-3 mRNA in Caco-2 cells treated with $1,1.5$, or $2 \mathrm{mM}$ sodium butyrate for $48 \mathrm{~h}\left(\mathrm{n}=3,{ }^{*} \mathrm{P}<0.05\right.$, $* * \mathrm{P}<0.01)$. (B and $\mathrm{C}$ ) Expression of Claudin-3 protein in Caco- 2 cells treated with $1.5 \mathrm{mM}$ sodium butyrate for 0,24 , or $48 \mathrm{~h}(\mathrm{n}=3$, ${ }^{*} \mathrm{P}<0.05,{ }^{* *} \mathrm{P}<0.01$ ).

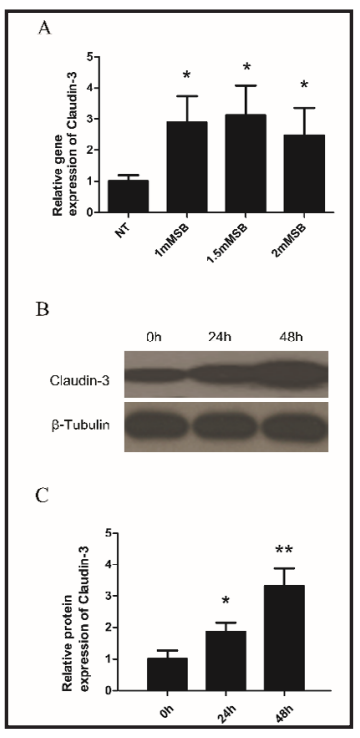

Sodium butyrate up-regulates Claudin-3 expression and TEER via the GPR109A/ Akt pathway

GPR109A shRNA was used to silence GPR109A expression in Caco-2 cells and to determine whether GPR109A mediates the effects of sodium butyrate on Claudin-3 expression in the colon. After knocking down GPR109A expression using shRNA (Fig. 6A, B, and $\mathrm{C}$ ), the activation of Akt induced by sodium butyrate was partly inhibited (Fig. 6E and F). Claudin-3 expression was examined in sodium butyrate-treated Caco-2 cells transfected with or without GPR109A shRNA using quantitative real-time PCR and western blotting 
Fig. 5. Effect of TNF- $\alpha$ on the expression of Claudin-3 with or without sodium butyrate. (A) Expression of Claudin-3 mRNA in Caco- 2 cells. The sodium butyrate + TNF- $\alpha$ group was pre-incubated with $1.5 \mathrm{mM}$ sodium butyrate for 1 $\mathrm{h}$ followed by incubation with 150 $\mathrm{ng} / \mathrm{mL}$ TNF- $\alpha$ for $48 \mathrm{~h}$; the TNF- $\alpha$

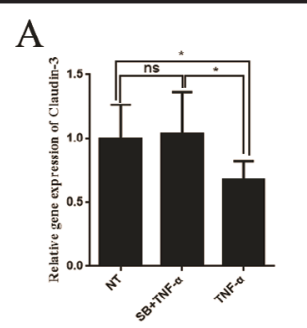

B

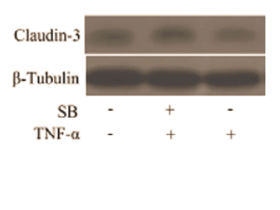

C

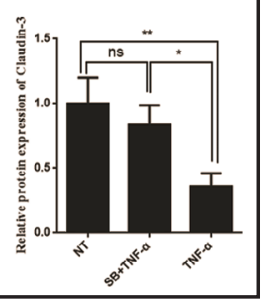

group was incubated with $150 \mathrm{ng} / \mathrm{mL}$ TNF- $\alpha$ only for $48 \mathrm{~h}\left(\mathrm{n}=3,{ }^{*} \mathrm{P}<0.05,{ }^{* *} \mathrm{P}<0.01\right)$. (B and C) Expression of Claudin-3 protein in Caco- 2 cells with or without $1.5 \mathrm{mM}$ sodium butyrate pre-incubation for $1 \mathrm{~h}$ followed by incubation with $150 \mathrm{ng} / \mathrm{mL}$ TNF- $\alpha$ for $48 \mathrm{~h}\left(\mathrm{n}=3,{ }^{*} \mathrm{P}<0.05,{ }^{* *} \mathrm{P}<0.01\right)$.

Fig. 6. Sodium butyrate promotes Claudin-3 expression and Akt phosphorylation, and increases colonic epithelium TEER via GPR109A. (A) The shRNA plasmid reduced the expression of GPR109A mRNA in Caco-2 cells, but the NC plasmid failed to decrease the levels of GPR109A mRNA ( $\mathrm{n}=3,{ }^{*} \mathrm{P}<0.05,{ }^{*} \mathrm{P}<0.01$ ). (B) Representative immunoblotting and (C) relative quantification analyses of GPR109A protein ( $\mathrm{n}=$ $3,{ }^{*} \mathrm{P}<0.05,{ }^{*} \mathrm{P}<0.01$ ). (D) TEER in Caco-2 cells transfected with $30 \mathrm{ng} / \mu \mathrm{L}$ shRNA plasmids ( $\mathrm{n}=$ $3, * \mathrm{P}<0.05, * * \mathrm{P}<0.01$ ). (E) Representative immunoblotting and $(\mathrm{F})$ relative quantification analyses of Akt in Caco- 2 cells at 15 min after

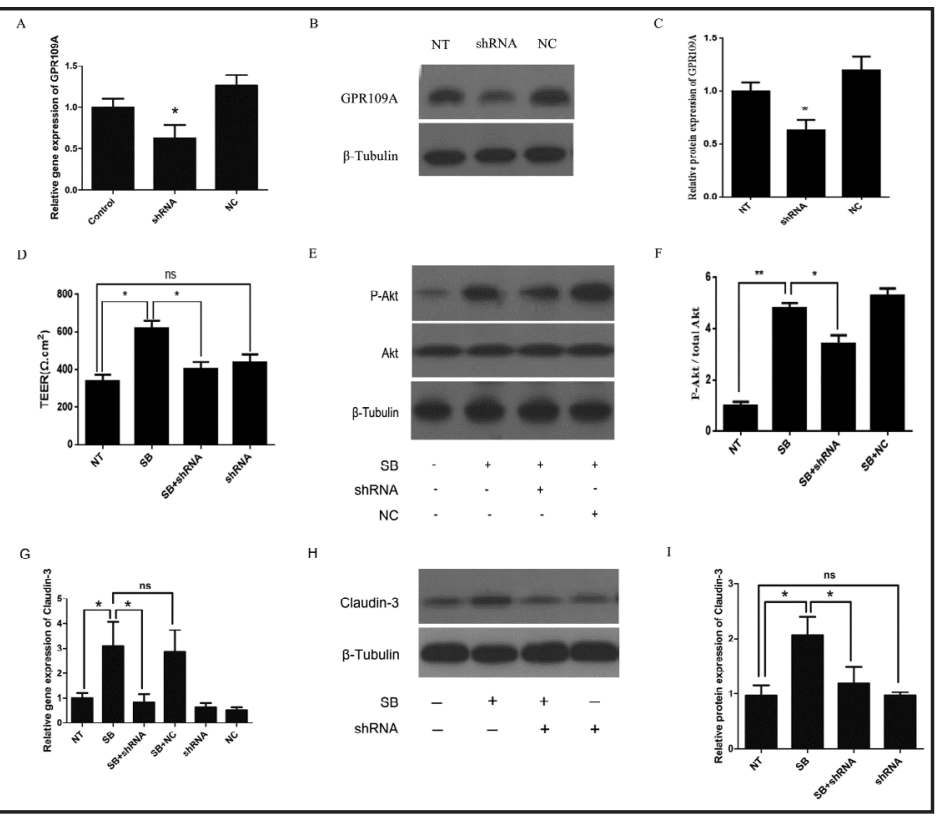
GPR109A-shRNA knockdown ( $\mathrm{n}=$ $\left.3,{ }^{*} \mathrm{P}<0.05,{ }^{* *} \mathrm{P}<0.01\right)$. (G) Claudin-3 mRNA levels in Caco-2 cells transfected with $30 \mathrm{ng} / \mu \mathrm{L} \mathrm{NC}$ and shRNA plasmids ( $\mathrm{n}=3, * \mathrm{P}<0.05$, $\left.{ }^{* *} \mathrm{P}<0.01\right)$. ( $\mathrm{H}$ and $\mathrm{I}$ ) Expression of Claudin-3 protein in Caco-2 cells transfected with $30 \mathrm{ng} / \mu \mathrm{L}$ shRNA plasmids $\left(\mathrm{n}=3,{ }^{*} \mathrm{P}<0.05\right.$, $\left.{ }^{* *} \mathrm{P}<0.01\right)$.

analyses. The effect of sodium butyrate on Claudin-3 expression was effectively impaired by the transfection of $30 \mathrm{ng} / \mathrm{mL}$ GPR109A shRNA, but not by a noncoding plasmid (NC) (Fig. 6G, H, and I). TEER was tested in sodium butyrate-treated cells transfected with or without GPR109A shRNA. The effect of sodium butyrate on TEER was effectively impaired by the transfection of $30 \mathrm{ng} / \mathrm{mL}$ GPR109A shRNA compared with the sodium butyrate group (P $<0.05$ ) (Fig. 6D). Caco-2 cells were pre-incubated with $10 \mu \mathrm{M}$ U0126 (a highly selective inhibitor of ERK kinase), $10 \mu \mathrm{M}$ MK2206 (an allosteric Akt inhibitor), and $10 \mu \mathrm{M}$ SB203580 (a specific inhibitor of P38) for $2 \mathrm{~h}$ followed by incubation with sodium butyrate for $4 \mathrm{~h}$ to elucidate whether the phosphorylation of ERK1/2, P38, and Akt is required for sodium butyrate-induced Claudin-3 expression in these cells. Sodium butyrate-induced Claudin-3 expression was blocked by MK2206 in Caco-2 cells compared with the sodium butyrate group ( $<$ < 0.05) (Fig. 7A, B, and C); however, U0126 and SB203580 had no effect on its expression ( $\mathrm{P}<0.05$ ) (Fig. 7D, E, and F). These results provided strong evidence that sodium butyrate increased Claudin-3 expression by activating Akt and reducing colon permeability. 
Fig. 7. Sodium butyrate up-regulates Claudin-3 expression via the Akt pathway. (A) Expression of Claudin-3 mRNA in Caco-2 cells pre-incubated with $10 \mu \mathrm{M}$ MK2206 (an allosteric Akt inhibitor) for $2 \mathrm{~h}$ followed by incubation with sodium butyrate for $4 \mathrm{~h}\left(\mathrm{n}=3,{ }^{*} \mathrm{P}<0.05\right.$, ${ }^{* *} \mathrm{P}<0.01$ ). (B and $\mathrm{C}$ ) Representative immunoblots and quantification of relative Claudin-3 protein levels in Caco-2 cells treated with or without $10 \mu \mathrm{M}$ MK2206 and

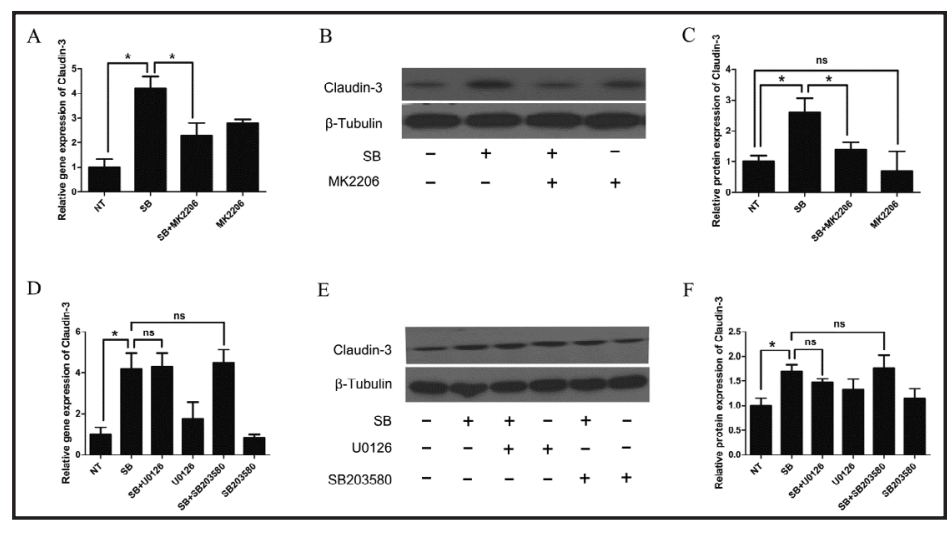
sodium butyrate $(\mathrm{n}=3, * \mathrm{P}<0.05$,

${ }^{* *} \mathrm{P}<0.01$ ). (D) Expression of Claudin-3 mRNA in Caco-2 cells pre-incubated with $10 \mu \mathrm{M}$ U0126 (a highly selective inhibitor of ERK kinase) and $10 \mu \mathrm{M}$ SB203580 (a specific inhibitor of P38) for $2 \mathrm{~h}$ followed by incubation with sodium butyrate for $4 \mathrm{~h}\left(\mathrm{n}=3{ }^{*} \mathrm{P}<0.05\right.$, $\left.{ }^{* *} \mathrm{P}<0.01\right)$. (E and $\mathrm{F}$ ) Representative immunoblots and quantification of relative Claudin-3 protein levels in Caco-2 cells pre-incubated with $10 \mu \mathrm{M}$ U0126 and $10 \mu \mathrm{M}$ SB203580 for $2 \mathrm{~h}$ followed by incubation with sodium butyrate for $4 \mathrm{~h}\left(\mathrm{n}=3,{ }^{*} \mathrm{P}<0.05,{ }^{* *} \mathrm{P}<0.01\right)$.

\section{Discussion}

The addition of organic acids to the diet of piglet is considered useful for overcoming post-weaning syndrome. The advantage of using butyrate rather than free acids is that it is generally tasteless and not volatile during feeding [18]. As a physiological small molecule that is produced by microbial fermentation, butyrate plays an important role in maintaining intestinal health. Compared with other short-chain fatty acids, butyric acid has received special attention. Our study did not reveal an obvious change in average daily feed intake, average daily gain, and the feed/gain ratio between the sodium butyrate and control groups, but sodium butyrate exerted a significant effect on ameliorating diarrhea. Sodium butyrate has been shown to relieve diarrhea caused by weaning stress or enterohemorrhagic Escherichia coli in piglets [19-21]. Moreover, butyrate therapy is beneficial in patients with congenital chloride diarrhea $[22,23]$, consistent with our results. In patients with Crohn's disease, butyrate decreases the expression of pro-inflammatory cytokines [24]. As shown in the study by Xu et al., early intervention with sodium butyrate modulates the inflammatory cytokine profile in the ileum of neonatal piglets [25]; notably, sodium butyrate effectively suppressed the expression of mRNA encoding the pro-inflammatory cytokine TNF- $\alpha$ in piglet colon tissue. Thus, sodium butyrate exerts positive effects on alleviating diarrhea and reducing inflammation.

Although the effects of butyrate on intestinal health have already been described in detail in many reports, the underlying mechanisms remain largely unknown. Evidence suggests a role for butyrate in reinforcing the colonic defense barrier. Butyrate increases the expression of the mucin 2 gene, and the induction of mucin synthesis in a human colonocyte cell line (LS174T) affects the mucous layer to enhance protection against luminal agents $[26,27]$. Butyrate also regulates the colonic defense barrier through its effects on intestinal permeability in a concentration-dependent manner. Butyrate induces a concentrationdependent reversible decrease in the permeability of intestinal cell line models $[8,28]$. In the present study, a 24-h treatment with $1 \mathrm{mM}$ sodium butyrate increased Claudin-3 expression in Caco-2 cells, which contributed to the enhancement of intestinal barrier function. Although we did not observe this effect following the administration of sodium butyrate at concentrations of less than $1 \mathrm{mM}, 1.5 \mathrm{mM}$ sodium butyrate also induced a timedependent increase in Claudin-3 expression. Ocejo et al. revealed the beneficial effects of a 


\section{Cellular Physiology Cell Physiol Biochem 2018;47:1617-1629 \\ \begin{tabular}{c|c|c|} 
DOI: 10.1159/000490981 & O 2018 The Author(s). Published by S. Karger AG, Basel \\
wwww.karger.com/cpb
\end{tabular} \\ Feng et al.: Sodium Butyrate Promotes Claudin-3 Expression in Colon via GPR109A}

diet supplemented with both whey and coated calcium butyrate on duodenal villus integrity and decreased mortality in chickens [29]. As described above, the intestinal barrier plays an important role in maintaining intestinal health. Butyrate exerts an effect on several components of this barrier [30], including tight junctions [31]. According to Huang et al., sodium butyrate decreases small intestinal permeability and increases intestinal Occludin expression [17]. In the present study, we confirmed that butyrate increased the expression of the tight junction proteins Claudin-3, Occludin, and ZO-1 in the colon in vivo and in vitro, contributing to the alleviation of diarrhea in weaned piglets.

Sodium butyrate activates Akt and ERK1/2 in different cells [32]. The effect of butyrate on intestinal epithelial permeability involves the assembly of tight junctions via AMPK [7]. As shown in a study by Miao, sodium butyrate activates the calcium/calmodulin-dependent protein kinase kinase $\beta$ pathway to mediate AMPK phosphorylation and contributes to the reassembly of tight junctions in Caco-2 cells [15]. Sodium butyrate improves oxidative stress by activating Akt in hepatocellular carcinoma cells [33]. On the basis of recent evidence, AIM2 contributes to the expression of the tight junction protein Claudin-3 via Akt and protects against mucosal Salmonella infections [34]. In the present study, the levels of phosphorylated ERK1/2, P38, and Akt were significantly increased in the colon of weaning piglets in the sodium butyrate group compared to the control group. Correspondingly, the levels of phosphorylated ERK1/2 and Akt were increased in Caco-2 cells after a 15-min treatment with sodium butyrate. Akt activation has been shown to increase Claudin-3 expression [34]. According to Yan et al., butyrate might increase the levels of tight junction proteins through mechanisms such as the activation of Akt/mTOR-mediated protein synthesis [35]. Here, sodium butyrate-induced Claudin-3 expression was blocked by MK2206 in Caco-2 cells. This finding provided solid evidence that Akt phosphorylation is essential for the sodium butyrate-mediated up-regulation of Claudin-3 expression in the colon.

GPR109A is G protein-coupled receptor for nicotinate [12, 36], and sodium butyrate plays a role in activating G protein-coupled receptors, such as GPR43 [37] and GPR109A, in different cell types. A study by Thangaraju et al. suggested a novel mode of action for butyrate in the colon that involved GPR109A. The inhibition of DNA methylation in colon cancer cells induces GPR109A expression, and the activation of this receptor causes tumor cell-specific apoptosis [38]. Corrêa et al. found that sodium butyrate activates GPR109A to regulate the function of immune cells [39]. As shown in the studies conducted by Cresci, tributyrin protects mice from ethanol-induced gut injury by increasing the expression and co-localization of tight junction proteins (ZO-1 and Occludin) and the expression of a butyrate receptor (GPR109A) in the ileum and proximal colon [40]. However, no report identified GPR109A in swine until we discovered that the AMP010014A09 gene in Sus scrofa encodes an analog of GPR109A that mediates the anti-inflammatory effects of beta-hydroxybutyric acid [16]. In the present study, $30 \mathrm{ng} / \mathrm{mL}$ GPR109A-shRNA plasmid was used to knock down GPR109A; the efficiency of interference was 35\%, which was due to limitations of the method used and the characteristics of plasmid interference in this cell line. However, the effect of sodium butyrate on Claudin-3 expression was effectively eliminated by GPR109A shRNA. Thus, GPR109A mediates the sodium butyrate-induced enhancement of intestinal barrier function.

\section{Conclusion}

Sodium butyrate acts on the Akt signaling pathway to facilitate Claudin-3 expression in a GPR109A-dependent manner. Depending on the tissues and cells, GPR109A activation may trigger a series of signaling pathways and subsequently alter the expression of the tight junction protein Claudin-3 to influence the intestinal permeability of piglets during the early weaning period. 


\section{Cellular Physiology Cell Physiol Biochem 2018;47:1617-1629

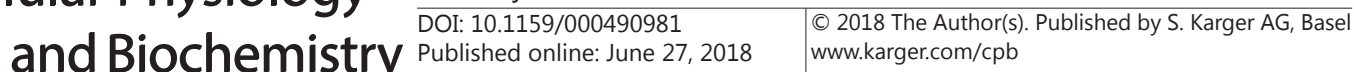 \\ Feng et al.: Sodium Butyrate Promotes Claudin-3 Expression in Colon via GPR109A}

\section{Acknowledgements}

This work was funded by the National Nature Science Foundation of China (31572479, 31602020, 2016YFD0501210) and Graduate Innovation Fund of Jilin University (project no. 2014117).

Wei Wang and Ju-Xiong Liu conceived of the idea and designed the project; Wen-Qian Feng, Yancheng Wu, Guang-Xin Chen, Shou-Peng Fu, Bai Li, and Bing-Xu Huang performed the experiments. Wen-Qian Feng, Yancheng Wu, Shou-Peng Fu, and Guang-Xin Chen analyzed the data. Wei Wang and Wen-Qian Feng wrote the manuscript. All authors have read and approved the final manuscript. Wen-Qian Feng, Yancheng Wu, Guang-Xin Chen, and ShouPeng Fu contributed equally to this work.

\section{Disclosure Statement}

The authors declare to have no conflict of interests.

\section{References}

1 Yang KM, Jiang ZY, Zheng CT, Wang L, Yang XF: Effect of Lactobacillus plantarum on diarrhea and intestinal barrier function of young piglets challenged with enterotoxigenic Escherichia coli K88. J Anim Sci 2014;92:1496-1503.

-2 Partanen KH, Mroz Z: Organic acids for performance enhancement in pig diets. Nutr Res Rev 1999;12:117145.

- 3 Han M, Song PX, Huang C, Rezaei A, Farrar S, Brown MA, Ma X: Dietary grape seed proanthocyanidins (GSPs) improve weaned intestinal microbiota and mucosal barrier using a piglet model. Oncotarget 2016;7:80313-80326.

4 Huang C, Song P, Fan P, Hou C, Thacker P, Ma X: Dietary Sodium Butyrate Decreases Postweaning Diarrhea by Modulating Intestinal Permeability and Changing the Bacterial Communities in Weaned Piglets. J Nutr 2015;145:2774-2780.

5 Wang XK, He G, Peng Y, Zhong WT, Wang Y, Zhang B: Sodium butyrate alleviates adipocyte inflammation by inhibiting NLRP3 pathway. Sci Rep 2015;5:12676.

6 Wang PY, Wang PY: Butyrate Enhances Intestinal Epithelial Barrier Function via Up-Regulation of Tight Junction Protein Claudin-1 Transcription. Gastroenterology 2012;142:S807-S807.

7 Peng L, Li ZR, Green RS, Holzman IR, Lin J: Butyrate enhances the intestinal barrier by facilitating tight junction assembly via activation of AMP-activated protein kinase in Caco-2 cell monolayers. J Nutr 2009;139:1619-1625.

-8 Peng L, He Z, Chen W, Holzman IR, Lin J: Effects of butyrate on intestinal barrier function in a Caco-2 cell monolayer model of intestinal barrier. Pediatr Res 2007;61:37-41.

-9 Fang CL, Sun H, Wu J, Niu HH, Feng J: Effects of sodium butyrate on growth performance, haematological and immunological characteristics of weanling piglets. J Anim Physiol Anim Nutr (Berl) 2014;98:680-685.

10 Ahmed K, Tunaru S, Offermanns S: GPR109A, GPR109B and GPR81, a family of hydroxy-carboxylic acid receptors. Trends Pharmacol Sci 2009;30:557-562.

-11 Tunaru S, Kero J, Schaub A, Wufka C, Blaukat A, Pfeffer K, Offermanns S: PUMA-G and HM74 are receptors for nicotinic acid and mediate its anti-lipolytic effect. Nat Med 2003;9:352-355.

-12 Wise A, Foord SM, Fraser NJ, Barnes AA, Elshourbagy N, Eilert M, Ignar DM, Murdock PR, Steplewski K, Green A, Brown AJ, Dowell SJ, Szekeres PG, Hassall DG, Marshall FH, Wilson S, Pike NB: Molecular identification of high and low affinity receptors for nicotinic acid. J Biol Chem 2003;278:9869-9874.

13 Fu SP, Wang JF, Xue WJ, Liu HM, Liu BR, Zeng YL, Li SN, Huang BX, Lv QK, Wang W, Liu JX: Anti-inflammatory effects of BHBA in both in vivo and in vitro Parkinson's disease models are mediated by GPR109Adependent mechanisms. J Neuroinflamm 2015;12: 1-14. 


\section{Cellular Physiology Cell Physiol Biochem 2018;47:1617-1629 \begin{tabular}{l|l} 
and Biochemistry & DOI: 10.1159/000490981 \\
Published online: June 27, 2018 & $\begin{array}{l}\text { (c) } 2018 \text { The Author(s). Published by S. Karger AG, Basel } \\
\text { www.karger.com/cpb }\end{array}$
\end{tabular}

14 Singh N, Gurav A, Sivaprakasam S, Brady E, Padia R, Shi H, Thangaraju M, Prasad PD, Manicassamy S, Munn DH, Lee JR, Offermanns S, Ganapathy V: Activation of Gpr109a, receptor for niacin and the commensal metabolite butyrate, suppresses colonic inflammation and carcinogenesis. Immunity 2014;40:128-139.

15 Miao W, Wu X, Wang K, Wang W, Wang Y, Li Z, Liu J, Li L, Peng L: Sodium Butyrate Promotes Reassembly of Tight Junctions in Caco-2 Monolayers Involving Inhibition of MLCK/MLC2 Pathway and Phosphorylation of PKCbeta2. Int J Mol Sci 2016;17:1696.

-16 Chen G, Fu S, Feng W, Huang B, Xu S, Wang W, Liu J: AMP010014A09 in Sus Scrofa Encodes an Analog of G Protein-Coupled Receptor 109A, Which Mediates the Anti-Inflammatory Effects of Beta-Hydroxybutyric Acid. Cell Physiol Biochem 2017;42:1420-1430.

17 Kang P, Toms D, Yin Y, Cheung Q Gong J, De Lange K, Li J: Epidermal growth factor-expressing Lactococcus lactis enhances intestinal development of early-weaned pigs. J Nutr 2010;140:806-811.

18 Guilloteau P, Martin L, Eeckhaut V, Ducatelle R, Zabielski R, Van Immerseel F: From the gut to the peripheral tissues: the multiple effects of butyrate. Nutr Res Rev 2010;23:366-384.

19 Piva A, Morlacchini M, Casadei G, Gatta PP, Biagi G, Prandini A: Sodium butyrate improves growth performance of weaned piglets during the first period after weaning. Italian J Anim Sci 2002;1:35-41.

20 Biagi G, Piva A, Moschini M, Vezzali E, Roth FX: Performance, intestinal microflora, and wall morphology of weanling pigs fed sodium butyrate. J Anim Sci 2007;85:1184-1191.

21 Takao M, Yen HL, Tobe T: LeuO enhances butyrate-induced virulence expression through a positive regulatory loop in enterohaemorrhagic Escherichia coli. Mol Microbiol 2014;93:1302-1313.

22 Canani RB, Terrin G, Cirillo P, Castaldo G, Salvatore F, Cardillo G, Coruzzo A, Troncone R: Butyrate as an effective treatment of congenital chloride diarrhea. Gastroenterol 2004;127:630-634.

23 Wedenoja S, Holmberg C, Hoglund P: Oral butyrate in treatment of congenital chloride diarrhea. Am J Gastroenterol 2008;103:252-254.

-24 Segain JP, de la Bletiere DR, Bourreille A, Leray V, Gervois N, Rosales C, Ferrier L, Bonnet C, Blottiere HM, Galmiche JP: Butyrate inhibits inflammatory responses through NF kappa B inhibition: implications for Crohn's disease. Gut 2000;47:397-403.

-25 Xu JM, Chen X, Yu SQ, Su Y, Zhu WY: Effects of Early Intervention with Sodium Butyrate on Gut Microbiota and the Expression of Inflammatory Cytokines in Neonatal Piglets. Plos One 2016;11:e0162461.

26 Hatayama H, Iwashita J, Kuwajima A, Abe T: The short chain fatty acid, butyrate, stimulates MUC2 mucin production in the human colon cancer cell line, LS174T. Biochem Biophys Res Commun 2007;356:599-603.

27 Willemsen LEM, Koetsier MA, van Deventer SJH, van Tol EAF: Short chain fatty acids stimulate epithelial mucin 2 expression through differential effects on prostaglandin E-1 and E-2 production by intestinal myofibroblasts. Gut 2003;52:1442-1447.

28 Mariadason JM, Barkla DH, Gibson PR: Effect of short-chain fatty acids on paracellular permeability in Caco-2 intestinal epithelium model. Am J Physiol 1997;272:G705-712.

-29 Ocejo M, Oporto B, Juste RA, Hurtado A: Effects of dry whey powder and calcium butyrate supplementation of corn/soybean-based diets on productive performance, duodenal histological integrity, and Campylobacter colonization in broilers. BMC Vet Res 2017;13:199.

-30 Canani RB, Costanzo MD, Leone L, Pedata M, Meli R, Calignano A: Potential beneficial effects of butyrate in intestinal and extraintestinal diseases. World J Gastroenterol 2011;17:1519-1528.

-31 Mitic LL, Van Itallie CM, Anderson JM: Molecular physiology and pathophysiology of tight junctions I. Tight junction structure and function: lessons from mutant animals and proteins. Am J Physiol Gastrointest Liver Physiol 2000;279:G250-254.

-32 Xu DB, Wu XY, Grabauskas G, Owyang C: Butyrate-induced colonic hypersensitivity is mediated by mitogenactivated protein kinase activation in rat dorsal root ganglia. Gut 2013;62:1466-1474.

-33 Pant K, Saraya A, Venugopal SK: Oxidative stress plays a key role in butyrate-mediated autophagy via Akt/ mTOR pathway in hepatoma cells. Chem Biol Interact 2017;273:99-106.

34 Hu GQ, Song PX, Li N, Chen W, Lei QQ, Yu SX, Zhang XJ, Du CT, Deng XM, Han WY, Yang YJ: AIM2 contributes to the maintenance of intestinal integrity via Akt and protects against Salmonella mucosal infection. Mucosal Immunol 2016;9:1330-1339.

-35 Yan H, Ajuwon KM: Butyrate modifies intestinal barrier function in IPEC-J2 cells through a selective upregulation of tight junction proteins and activation of the Akt signaling pathway. Plos One 2017;12:e0179586. 


\section{Cellular Physiology Cell Physiol Biochem 2018;47:1617-1629 \begin{tabular}{ll|l} 
DOI: 10.1159/000490981 & O 2018 The Author(s). Published by S. Karger AG, Basel \\
www.karger.com/cpb
\end{tabular}}

Feng et al.: Sodium Butyrate Promotes Claudin-3 Expression in Colon via GPR109A

-36 Soga T, Kamohara M, Takasaki J, Matsumoto S, Saito T, Ohishi T, Hiyama H, Matsuo A, Matsushime H, Furuichi K: Molecular identification of nicotinic acid receptor. Biochem Biophys Res Commun 2003;303:364-369.

-37 Maslowski KM, Vieira AT, Ng A, Kranich J, Sierro F, Yu D, Schilter HC, Rolph MS, Mackay F, Artis D, Xavier RJ, Teixeira MM, Mackay CR: Regulation of inflammatory responses by gut microbiota and chemoattractant receptor GPR43. Nature 2009;461:1282-U1119.

-38 Thangaraju M, Cresci GA, Liu K, Ananth S, Gnanaprakasam JP, Browning DD, Mellinger JD, Smith SB, Digby GJ, Lambert NA, Prasad PD, Ganapathy V: GPR109A is a G-protein-coupled receptor for the bacterial fermentation product butyrate and functions as a tumor suppressor in colon. Cancer Res 2009;69:28262832.

39 Correa-Oliveira R, Fachi JL, Vieira A, Sato FT, Vinolo MA: Regulation of immune cell function by short-chain fatty acids. Clin Transl Immunol 2016;5:e73.

$\checkmark 40$ Cresci GA, Bush K, Nagy LE: Tributyrin supplementation protects mice from acute ethanol-induced gut injury. Alcohol Clin Exp Res 2014;38:1489-1501. 